\title{
Early Osseous Tissue Formation Associated to Submerged and Non-Submerged Dental Implants. A Histomorphometric Animal Study
}

\author{
Formación Temprana de Tejido Óseo Asociado a Implantes Dentales Sumergidos \\ y no Sumergidos. Un Estudio Histomorfométrico Animal
}

"Sergio Olate; ${ }^{* *}$ Henrique Duque de Miranda Chaves Netto; ${ }^{* * *}$ Renato Mazzonetto \& ${ }^{* * *}$ Jose Ricardo de Albergaria-Barbosa

OLATE, S.; CHAVES NETTO, H. D. M.; MAZZONETTO, R. \& ALBERGARIA-BARBOSA, J. R. Early osseous tissue formation associated to submerged and non-submerged dental implants. A histomorphometric animal study. Int. J. Morphol., 30(1):130-135, 2012.

SUMMARY: The purpose of this research was to compare the bone formation around submerged and non-submerged implants installed in a mandible of dog. Seven beagle dogs were used in this protocol; initially, was performed extraction of posterior teeth of mandible and after 3 month healing were installed two dental implants with surface treatment (subtraction of titanium via acidification) in each hemimandible. A transmucosal healing screw of $7 \mathrm{~mm}$ without oclusal contact was installed at the anterior implant as a model of non-submerged implant; in the posterior implant were installed a cover screw, using the submerged technique. After six weeks of healing, histomorphometric analysis of osseous tissue between the threads was performed. Was analyzed the implant unit as well as the cervical, meddle and apical region of implant. Student $t$ test with 5\% significance was used. The non-submerged implant model showed more bone formation than submerged implant without statistically significance $(\mathrm{p}=0.106)$; for regional analyses, cervical area shows more osseous formation than middle and apical areas. The regional analyses did not present statistical difference between areas for comparative analysis of submerged and non-submerged implant model. Non-submerged implant model it's not an obstacle for osseous formation.

KEY WORDS: Dental implant; Non-submerged implant; Bone repair.

\section{INTRODUCTION}

The success of dental implant has been reported in the international literature (Buser et al., 1997; Chiapasco et al., 1997). In almost all of them, the standard protocol of Brånemark (two-stage surgery), is a prerequisite, leaving the implant submerged for 3 to 6 months. The primary objective was to allow the osseointegration and stability of these implants (Brånemark et al., 1969) because early or immediate loading were related to fibrous tissue encapsulation and poor capacity of bone for stress support, leaving necrotic bone to implants contact (Brånemark, 1983). On the other hand, clinical researches and animal studies demonstrated that when implants are immediately loaded, osseointegration can occur without modifications or alterations as two-stage implants (Chiapasco et al., Romanos et al., 2001; Meyer et al., 2003; Nkenke et al., 2005). Advantages to one-stage implant surgery are to reduce number of surgeries and decrease total treatment time (Becker et al. 1997).
Success of osseointegration can be associated to bone quality, implant stability and immobilization (Meyer et al.; Romanos et al., 2002; Romanos et al., 2003; Morris et al., 2003), because its early movement can be related to implant failure (Pillar et al., 1986); however, the implant micromovement can be important for osseointegration and implant success (Nkenke \& Fenner, 2006).

Becker et al. in a prospective multicenter research evaluated the clinical outcomes of one-stage implants, installed immediately after tooth extraction with transmucosal healing abutments, showed $95.6 \%$ success in one year follow-up. Ericcson et al. (1994) placed one- and two-stage implants into edentulous human mandibles and reported $100 \%$ survival implants for both techniques in a short-term follow-up. 
Weber et al. (1996) evaluated submerged and nonsubmerged implants in an animal model; the plasma-sprayed titanium implants showed similar distances from tops of implants to the bone crest for both submerged and nonsubmerged implants. Another report of Ericcson et al. (1996) compared healing times for one-stage implants and two-stage implants in dogs for a six month follow-up; the marginal bone loss for one-stage implants was $2.6 \mathrm{~mm}$ and for twostage implants was $2.1 \mathrm{~mm}$. Gotfredsen et al. (1991) analyzed responses to submerged and non submerged implants in monkeys with histomorphometric analysis without differences between them.

The aim of this research was to evaluate the early periimplant bone formation in dog jaws with submerged and non-submerged implants originally used for two stage surgery.

\section{MATERIAL AND METHOD}

Experimental Model. Seven male beagles dogs, 3 to 5 years of age with a body weight between 10.4 and $21.3 \mathrm{~kg}$ were maintained with commercial diet and water. Bilateral mandible bicuspid were extracted, with a 3-months healing time. Two implants (Neodent ${ }^{\circledR}$, Curitiba, Brazil and Conexão®, São Paulo, Brazil) with a length of $11 \mathrm{~mm}$ and diameter of $3.75 \mathrm{~mm}$ were placed in each hemimandible; the implants presented surface treatment by subtraction of titanium via acidification. In accordance with the experimental model, non-submerged implant was installed $6 \mathrm{~mm}$ posterior to proximal teeth with a healing screw of $7 \mathrm{~mm}$, without oclusal contact. Submerged implant was installed $6 \mathrm{~mm}$ posterior to non-submerged implant with a cover screw (Fig. 1). This study was approved by the Animal Ethics Committee of the State University of Campinas under reference number 1261-1.

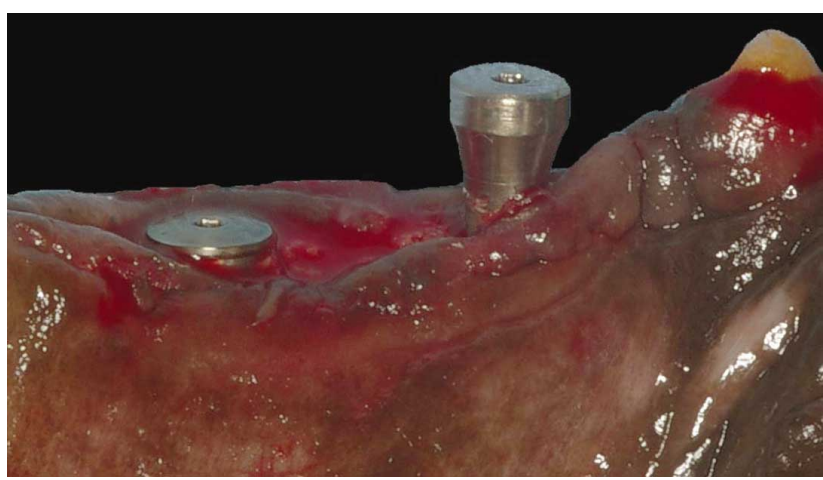

Fig. 1. Submerged and non-Submerged models in dog mandible. For proximal implant were installed a transmucosal healing screw; for posterior implant were installed the cover screw.
Surgical Procedure. All surgical procedures were performed in a veterinary surgical room. The animals were submitted to anesthesia with an intramuscular ketamine $(10 \mathrm{mg} / \mathrm{kg})$, atropine $(0.06 \mathrm{mg} / \mathrm{kg})$ and xilazine clorhidrate $(0.03 \mathrm{ml} / \mathrm{kg})$; analgesic medication was applied with intramuscular metamizol $(25 \mathrm{mg} / \mathrm{kg})$. In all surgical procedure, tooth debris and calculus involving dentition were systematically removed.

For implant placement, a lineal incision with mucoperiosteal flap was executed; the socket was created using hand piece at low speed with $1,500 \mathrm{rpm} / \mathrm{min}$ and continuous external saline irrigation. The last burr used was a $3.0 \mathrm{~mm}$ diameter. The implants were installed by manual tapping into the sockets and the screws were fully embedded into bone; the shoulder of implants were placed $1 \mathrm{~mm}$ below the ridge crest. A cover screw was used in the posterior implant and $7 \mathrm{~mm}$ healing screw was used for the anterior implant. Suture was performed with absorbable material. The animals diet was comprised of soft commercial feed. The dogs were sacrificed 6 weeks after implant insertion by induction of deep anesthesia followed by an intravenous overdose of sodium pentobarbital.

Histomorphometric analysis. The specimen was submerged in $4 \%$ formalin and subsequently embedded in resin according to routine histological technique. Samples were cut longitudinally to the implant and stained with HE for light microscopy analysis. Histomorphometric analyses were executed with a point lineal analysis. The mineralized tissue within the threads in the cervical area was measured, middle and apical areas using 10X and 50X magnification; the analysis include three measurement area for each implants.

Statistical Analysis. Descriptive analysis and Student's t test were used to analyze 72 slices of 24 implants with a 5\% significance level $(\mathrm{p}<0.05)$ (Biostat 10.0 software).

\section{RESULTS}

Were not observed gaps or fibrous tissue in any of the 24 implants; for other hand, were not observed signs of tissue infection and did not existed vestibular or lingual perforations. Soft tissue reparation was observed without problem.

Histological Analysis. The histological situation of submerged and non-submerged implant was comparable in cervical, middle and apical areas (Figs. 2 and 3). All samples showed osseous repair with quantitative differences in count 


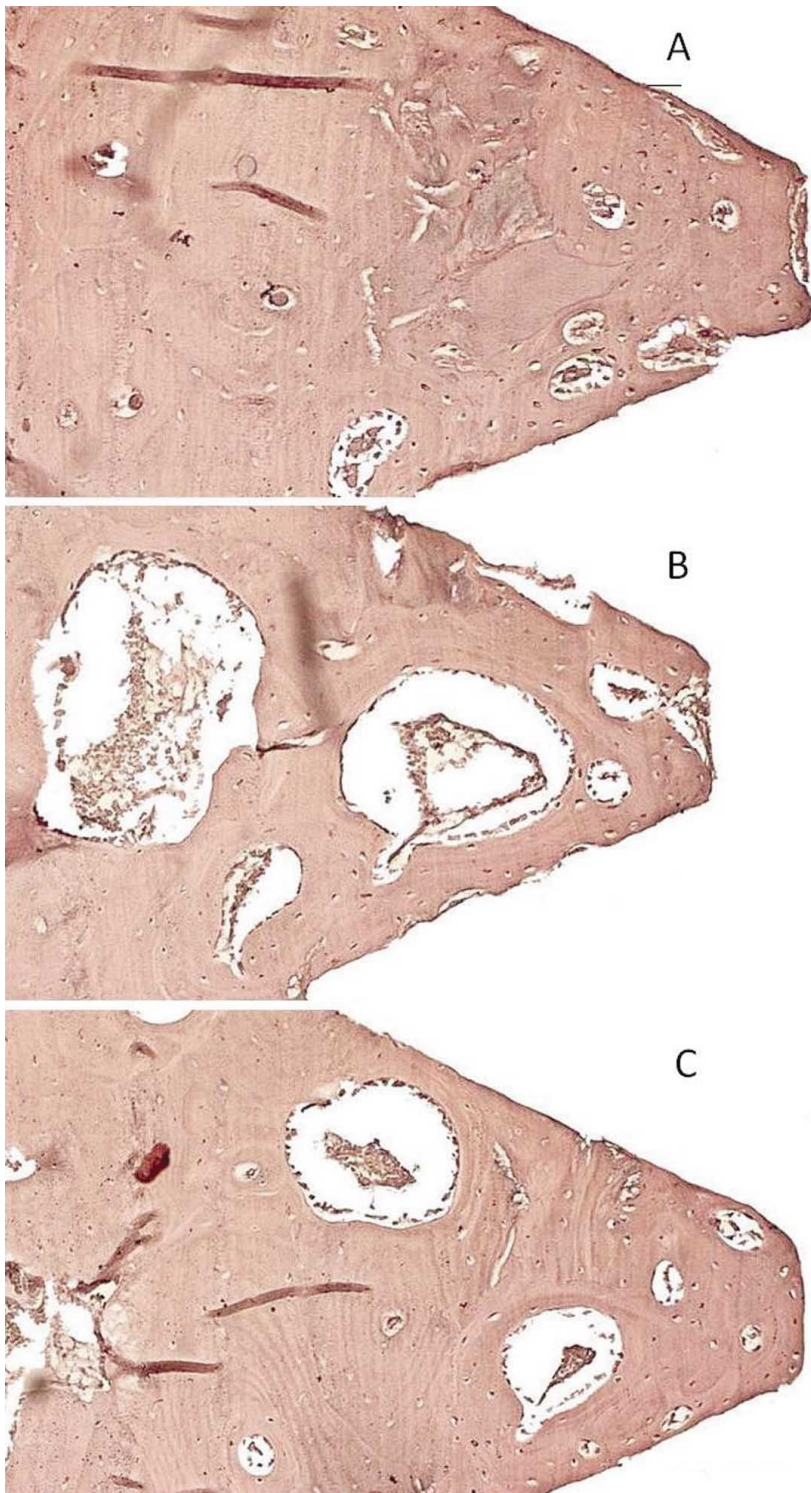

Fig. 2. Magnified view of the non-submerged specimens showing the osseous tissue between thread in cervical (A), meddle (B) and apical areas (C) (10X magnification).

of collagen fibrous and count of mineralized tissue. Differences between old bone and new bone were clearly observed and was osteoblast activity with sign of osseous apposition was also observed. Blood vessel was observed in some samples, principally in the peripheral area.

Histomorphometric Analysis. The mean values for bone within thread (BWT) for the non-submerged group was $29.9 \%( \pm 19.9 \%)$ and for the submerged group was $22.9 \%$ $( \pm 14.9 \%)$; no statistical significant difference was observed $(\mathrm{P}=0.106)$.
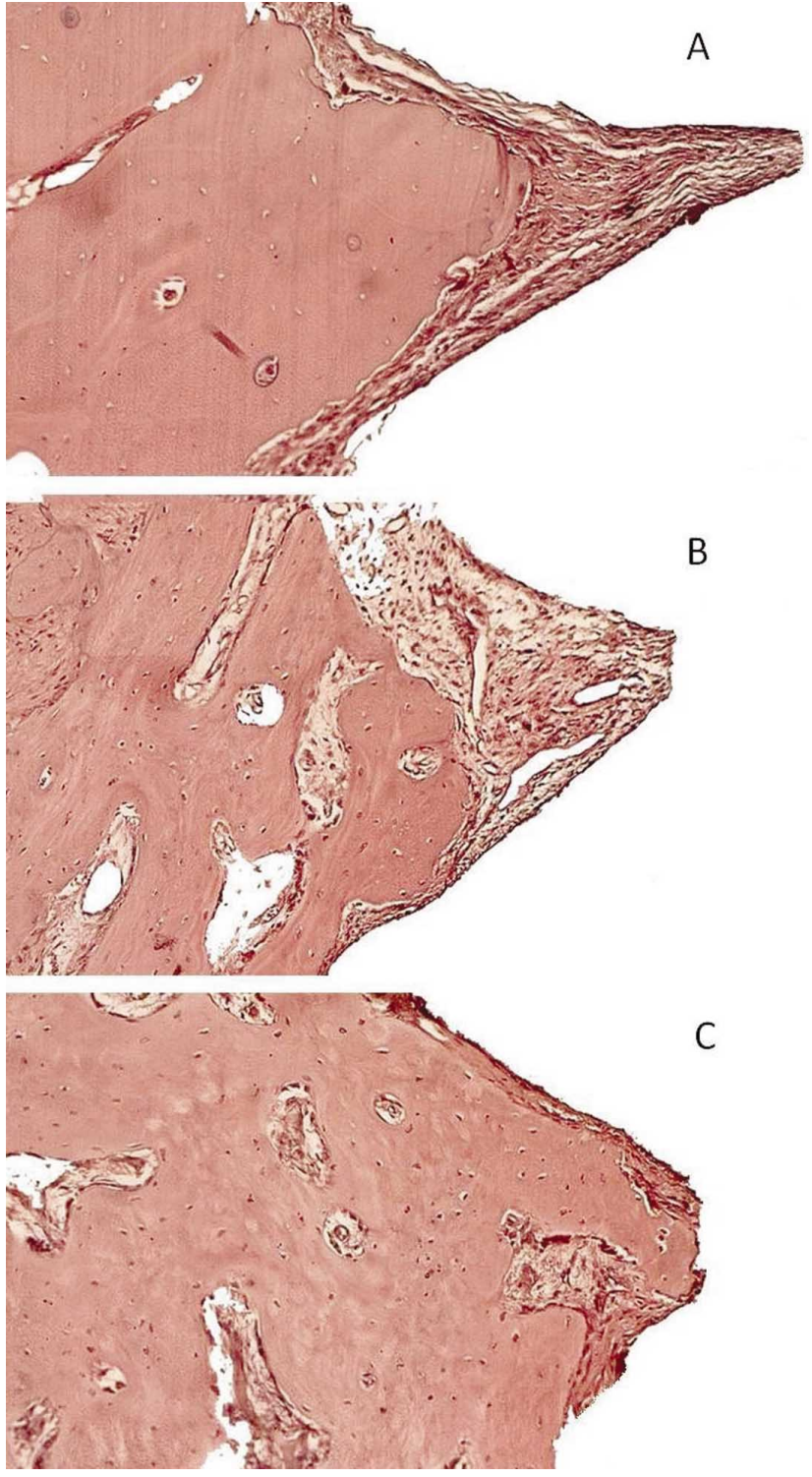

Fig. 3. Magnified view of the submerged specimens showing the osseous tissue between thread in cervical (A), meddle (B) and apical areas (C) (10X magnification).

The analysis of implant areas showed more osseous formation for non-submerged implant (Fig. 4), however none of analysis showed any statistically significant differences (Table I). The mean values for BWT was:

Cervical area: $29.3 \%( \pm 21.3 \%)$ for non-submerged implant and $27.1 \%( \pm 17.4 \%)$ for submerged implants.

Meddle area: $31.5 \%$ ( \pm 17.32$)$ for non-submerged implants group and $24.6 \%$ ( \pm 12.34$)$ for submerged group.

Apical area: $29.1 \%( \pm 23.1 \%)$ for non-submerged implants and $17.1 \%( \pm 10.9 \%)$ for submerged implants. 


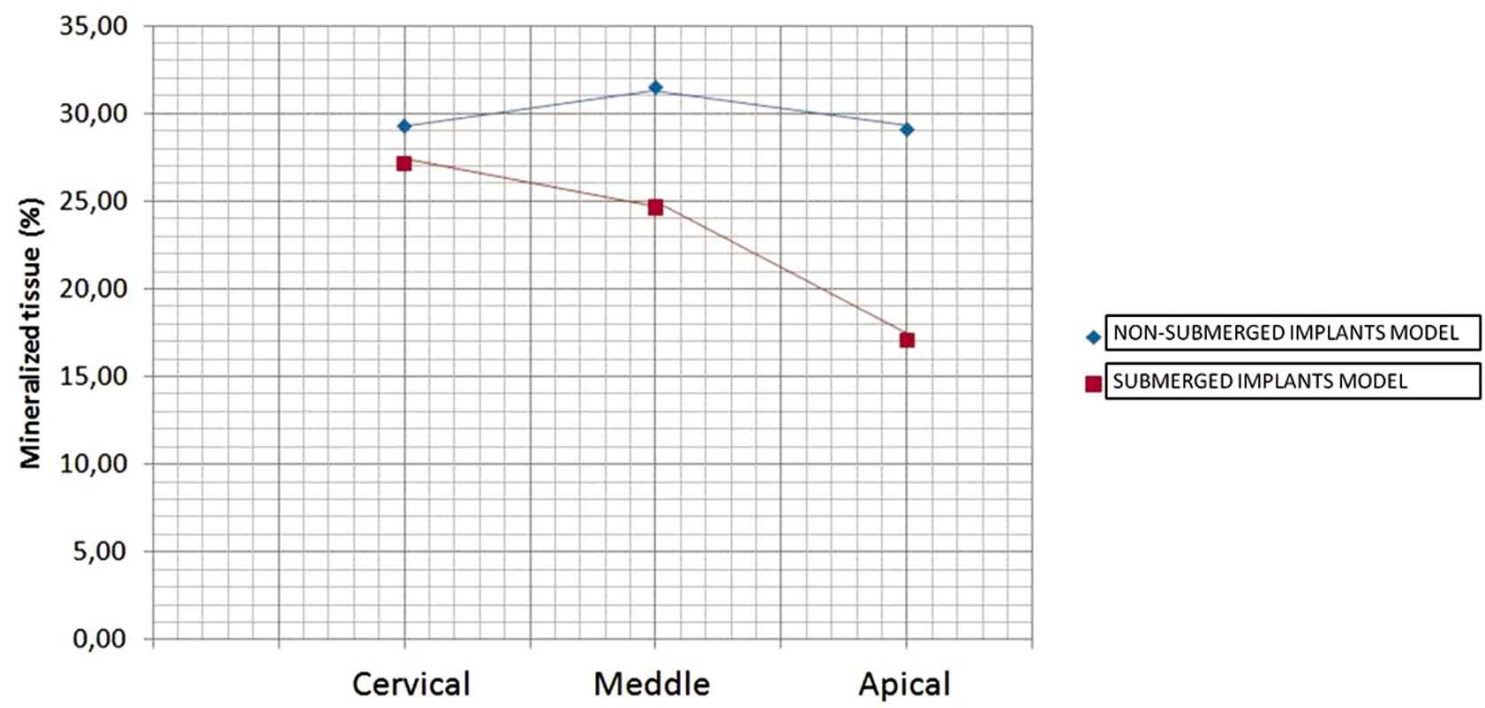

Fig. 4. Distribution of bone tissue within threads in cervical, middle and apical areas in submerged and non-submerged implants model.

Table I. Distribution of mineralized tissue between thread with histomorphometric analysis in submerged and nonsubmerged implant model. Percentage and statistical analysis without statistical significance (p>0.05).

\begin{tabular}{lccccc}
\hline Implant Analysis & \multicolumn{2}{c}{ Non-subme rged Implant Model } & \multicolumn{2}{c}{ Submerged Implant Model } & $\boldsymbol{p}$ (Student $\boldsymbol{t}$ test) \\
\cline { 2 - 5 } & $\boldsymbol{X}(\boldsymbol{\%})$ & SD $(\boldsymbol{\%})$ & $\boldsymbol{X}(\boldsymbol{\%})$ & SD $(\boldsymbol{\%})$ & \\
Implant Unit & 29.9 & 19.9 & 22.9 & 14.9 & 0.1057 \\
Cervical Area & 29.3 & 21.2 & 27.1 & 17.4 & 0.7874 \\
Middle Area & 31.5 & 17.3 & 24.6 & 12.3 & 0.2685 \\
Apical Area & 29.1 & 23.1 & 17.0 & 10.9 & 0.1541 \\
\hline
\end{tabular}

\section{DISCUSSION}

Histological findings showed that implants can become osseointegrated with submerged and non submerged techniques, although knowing that, for long-term stability, micromovements and macromovements of implants are an important factor for success (Maniatopoulus et al., 1986; Chausu et al., 2001). The fibrous encapsulation of implant represents a deviation from the normal bone healing pattern and can be interpreted as a defense mechanism against either a chemical or mechanical. Early responses around implants are characterized by inflammatory reactions, result of the surgical trauma and foreign material (Dhert et al., 1998, Hanawa et al., 1997). There is a general agreement that micromovements are biologically significant, especially if it begins at early stage after implantation (Chausu et al.). Pillars et al. showed that more than $30 \mu \mathrm{m}$ of movement can be enough for soft tissue formation and minimal osseous formation and Cameron et al. (1973) show that $150 \mu \mathrm{m}$ of movement is rapidly associated to soft tissue formation. If clinically it is difficult to determine the micromovement, the submerged protocol is an option.

In a randomized controlled clinical trial with 324 implants placed in maxilla and mandible, Cecchinato et al. (2004) demonstrated that tissue healing following to submerged and non-submerged implant were not presented statistical difference; the level of marginal bone was closed to the coronal rim of the implant and were associated principally to proper soft and hard tissue modeling.

Bone-implant contact around a 2-piece dental implant is dependent of location of the interface between implant and abutment. In this direction, significant crestal bone loss around 2-piece implant is related to location of the interface and is not related to submerged or non-submerged implant technique (Hermann et al., 2000); In other research it was observed that distance between implant top, coronal muco- 
sa and coronal bone-implant contact were similar for submerged and non-submerged technique (Weber et al.). Our research did not evaluate this issue, but we can recognize the same results of this research in our samples.

Choi et al. (2008) showed that average bone height was greater at submerged sites $(11.0 \pm 0.5 \mathrm{~mm})$ than nonsubmerged sites $(10.1 \pm 0.5 \mathrm{~mm})$; moreover, the average osseointegration was also greater at submerged sites $(64.7 \pm 8.0 \%)$ than at the non-submerged sites $(56.8 \pm 7.8 \%)$ with statistically significance. The authors suggested that submerged protocols can be used in sites with either poor bone quality or low primary implant stability. In our canine model, non-submerged implants showed more bone formation, suggesting more rapid response to prosthetic phase.

Levy et al. (1996), in an animal research, demonstrated that absolute bone-contact values were greater for submerged implants with statistical significance only on the buccal side. The results indicated no significant difference in bone contact in the coronal region, but with significant difference in the apical region where submerged implant design had more importance; finally, Levy et al. showed that submerged implant presented more bone-implant contact than non-submerged implant in a 6 week analysis. Our results show that in apical region more bone formation was observed related to non-submerged implant, without statistical difference In cervical area quantitatively, almost the same osseous tissue was present in submerged and non-submerged implant. These differences with others researches can be associated to the type, design and implant surface, since Weber et al. studied cylindrical press-fit implants and Levy et al. studied a mono-block implants without threaded.

Finally, our results showed that repair sequence of 2piece threaded non-submerged implants can be the same as submerged implants. According to these observations and considering the limitations of the study, non-submerged 2-piece implant is not an obstacle for normal osseous tissue formation.

OLATE, S.; CHAVES NETTO, H. D. M.; MAZZONETTO, R. \& ALBERGARIA-BARBOSA, J. R. Formación temprana de tejido óseo asociado a implantes dentales sumergidos y no sumergidos. Un estudio histomorfométrico animal. Int. J. Morphol., 30(1):130-135, 2012 .

RESUMEN: El objetivo de esta investigación fue comparar la formación ósea alrededor de implantes dentales sumergidos y no sumergidos instalados en mandíbula de perro. Siete perros Beagle fueron utilizados en este protocolo; inicialmente fueron realizadas las exodoncias de dientes posteriores de mandíbula y luego de 3 meses de recuperación fueron instalados dos implantes dentales con tratamiento de superficie en cada hemimandíbula (substracción de titanio vía acidificación). En el implante anterior fue instalado también un conector transmucoso de $7 \mathrm{~mm}$ sin contacto oclusal y en el implante posterior fue instalado el tornillo de cierre. Luego de 6 semanas de recuperación, se realizó un análisis histomorfométrico del tejido óseo presente entre las roscas. Se analizó el implante como unidad así como también sus sectores cervical, medio y apical. Se utilizó la prueba estadística t de student con 5\% de significancia estadística. El implante no sumergido presentó mayor formación ósea sin diferencias estadísticamente significativa ( $\mathrm{p}=0.106$ ); en los análisis regionales, el área cervical presentó mayor formación ósea que las áreas medianas y apicales. El análisis regional no presentó diferencias estadísticamente significativas entre ambos tipos de implante. El modelo de implante no sumergido no es un obstáculo para la formación ósea.

PALABRAS CLAVE: Implante dental; Implante no sumergido; Reparación ósea.

\section{REFERENCES}

Becker, W.; Becker, B. E.; Israelson, H.; Lucchini, J. P.; Handelsman, M.; Ammons, W.; Rosenberg, E.; Rose, L.; Tucker, L. \& Lekholm, U. One-Step Surgical Placement of Brånemark Implants: A Prospective Multicenter Clinical Study. Int. J. Oral Maxillofac. Implants, 12:454-62, 1997.

Buser, D.; Mericske-Stern, R.; Bernard, J. P.; Behneke, A.; Behneke, N.; Hirt, H. P.; Belser, U. C. \& Lang, N.P. Long-term evaluation of non-submerged ITI implant. Part I: an 8-year life table analysis of a prospective multi center study with 2359 implants. Clin. Oral Implants Res., 8:161-72, 1997.
Brånemark, P. I.; Adell, R.; Breine, U.; Hansson, B. O.; Lindstrom, J. \& Ohlsson, A. Intraosseous anchorage of dental prostheses. I. Experimental studies. Scand. J. Plast. Reconstr. Surg., 3:81100, 1969.

Brånemark, P. I. Osseointegration and its experimental background. J. Prosthet. Dent., 50:399-410, 1983.

Cameron, H. U.; Pillar, R. M. \& MacNab, I. The effect of movement on the bonding of porous metal to bone. J. Biomed. Mater. Res., 7:301-11, 1973. 
Cecchinato, C.; Olsson, C. \& Lindhe, J. Submerged or nonsubmerged healing of endosseous implants to be used in the rehabilitation of partially dentate patients. A multicenter, randomized controlled clinical trial. J. Clin. Periodontol., 31:299-308, 2004.

Chausu, G.; Chausu, S.; Tzohar, A. \& Dayan, D. Immediate loading of single-tooth implants: immediate versus non-immediate implantation: a clinical report. Int. J. Oral Maxillofac. Implants, 16:267-72, 2001.

Chiapasco, M.; Gratti, C.; Rossi, E.; Haefliger, W. \& Markwalder, T. H. Implant-retained mandibular overdentures with immediate loading. A retrospective multicenter study on 226 consecutives cases. Clin. Oral Implant Res., 8:48-57, 1997.

Choi, B. H.; Li, J.; Kim, H. S.; Ko, C. Y.; Jeong, S. M. \& Xuan, F. Comparison of submerged and nonsubmerged implants placed without flap reflection in the canine mandible. Oral Surg. Oral Med. Oral Pathol. Oral Radiol. Endod., 105:561-5, 2008.

Dhert, W. J.; Thomsen, P.; Blomgren, A. K.; Esposito, M.; Ericson, L. E. \& Verbout, A. J. Integration of press-fit implants in cortical bone: a study on interface kinetics. J. Biomed. Mater. Res., 15:574-83, 1998.

Ericcson, I.; Randow, K.; Glantz, P. O.; Lindhe, J. \& Nilner, K. Clinical and radiographical features of submerged and nonsubmerged titanium implants. Clin. Oral Implants Res., 5:185-9, 1994.

Ericcson, I.; Nilner, K.; Klinge, B. \& Glantz, P. O. Radiographical and histological characteristics of submerged and nonsubmerged titanium implants. An experimental study in the Labrador dog. Clin. Oral Implants Res., 7:20-6, 1996.

Gotfredsen, K.; Rostrup, E.; Hjørting-Hansen, E.; Stoltzke, K. \& Budtz-Jorgensen, E. Histological and histomorphometrical evaluation of tissue reactions adjacent to endosteal implants in monkeys. Clin. Oral Implants Res., 2:30-7, 1991.

Hanawa, T.; Kamiura, Y.; Yamamoto, S.; Kohgo, T.; Amemiya, A.; Ukai, H.; Murakami, K. \& Asaoka, K. Early bone formation around calcium-ion-implanted titanium inserted into rat tibia. J. Biomed. Mater. Res., 36:1311-6, 1997.

Hermann, J.; Buser, D.; Schenk, R. \& Cochran, D. Crestal bone changes around titanium implants. A histometric evaluation of unloaded non-submerged and submerged implants in the canine mandible. J. Periodontol., 71:1412-24, 2000.

Levy, D.; Deporter, D. A.; Piliar, R. M.; Watson, P. A. \& Valiquette, $\mathrm{N}$. Initial healing in the dog of submerged versus nonsubmerged porous-coated endosseous dental implants. Clin. Oral Implants Res., 7:101-10, 1996.

Maniatopoulus, C.; Pillar, R. M. \& Smith, D. Threated versus porous surface designs for implant stabilization in bone - endodontic implant model. J. Biomed. Mater. Res., 20:1309-33, 1986.
Meyer, U.; Wiesmann, H. P.; Fillies, T. \& Joos, U. Early tissue reaction at the interface of immediately loaded dental implants. Int. J. Oral Maxillofac. Implants, 18:489-99, 2003.

Morris, H. E.; Ochi, S.; Crum, P.; Orestein, I. \& Plezia, R. Bone density: its influence on implant stability after uncovering. $J$. Oral Implantol., 29:263-9, 2003.

Nkenke, E.; Fenner, M.; Vairaktaris, E. G.; Neukam, F. W. \& Radespiel-Troger, M. Immediate versus delayed loading of dental implants in the maxillae of minipigs. Part II: histomorphometric analysis. Int. J. Oral Maxillofac. Implants, 20:540-6, 2005.

Nkenke, E. \& Fenner, M. Indications for immediate loading of implants and implant success. Clin. Oral Implants Res., 17:1934, 2006.

Pilliar, R. M.; Lee, J. M. \& Maniatopoulos, C. Observation on the effect of movement on bone ingrowth into porous-surfaced implants. Clin. Orthop. Relat. Res., 208:108-13, 1986.

Romanos, G.; Toh, C. G.; Siar, C. H.; Swaminathan, D.; Ong, A. H.; Donath, K.; Yaacob, H. \& Nentwig, G. H. Peri-implant bone reactions to immediately loaded implants. An experimental study in monkeys. J. Periodontol., 72:506-11, 2001.

Romanos, G. E.; Toh, C. G.; Siar, C. H. \& Swaminathan, D. Histologic and histomorphometric evaluation of peri-implant bone subjected to immediate loading: an experimental study with macaca fascicularis. Int. J. Oral Maxillofac. Implants, 17:44-51, 2002.

Romanos, G. E.; Toh, C. G.; Siar, C. H.; Wicht, H.; Yacoob, H. \& Nentwig, G. H. Bone-implant interface around titanium implants under different loading conditions: a histomorphometrical analysis in the macaca fascicularis monkey. J. Periodontol., 74:1483-90, 2003.

Weber, H. P.; Buser, D.; Donath, K.; Fiorellini, J. P.; Doppalapudi, V.; Paquette, D. W. \& Williams, R. C. Comparison of healed tissues adjacent to submerged and non-submerged unloaded titanium dental implants. A histometric study in beagle dogs. Clin. Oral Implants Res., 7:11-9, 1996.

\section{Correspondence to:}

Prof. Dr. Sergio Olate, DDS, MSc, PhD

Facultad de Medicina

Universidad de La Frontera

Claro Solar $115,4^{\circ}$ piso,

Temuco

CHILE

Email: solate@ufro.cl

Received: 06-10-2011

Accepted: 06-11-2011 